\section{Clone your own legend}

IT is raining, but the last two bronzed customers at the bayside plaza café aren't leaving. This is Genentech, so they are obviously scientists in animated discussion. Hold on, these guys aren't going anywhere. They are statues of Bob Swanson and Herb Boyer, at the moment when, over That Beer, they founded Genentech, not even 20 years ago. And

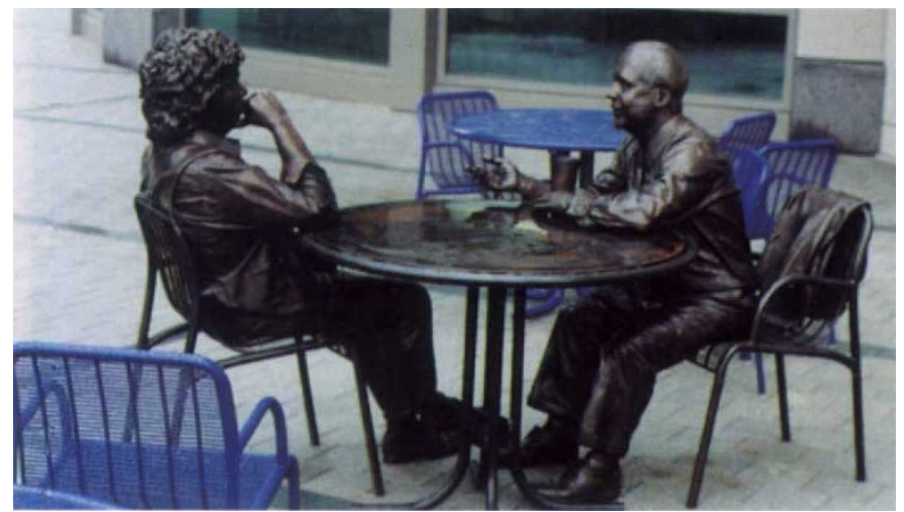

Permanent fixtures - Bob Swanson and Herb Boyer.

as if to votive ikons, their beer mugs are full of money. To a European, it seems hardly seemly that such a memorial could even be considered this side of 1776, let alone 1976, never mind that both protagonists are still alive. Such is the local mythopoeia in compensation for lack of history.

The Bob'n'Herb statue stands amid a brand new complex of buildings overlooking the bay, intended to house Genentech's entire research staff of 400 . The change is long overdue. "For the last ten years we worked in horrible conditions in a building that was a warehouse, that had no windows, a very poor ventilation system and a roof that leaked every time it rained: but people didn't care because the work was exciting", says Phil Berman (once a postdoc at the Salk: "the quintessential California dream lab - by the beach"), currently working on antiviral vaccine strategies. Genentech people tend to be stayers, starting at the bottom and working they way upwards. This, of course, imbues them with a strong sense of identity and corporate pride.

Nevertheless, they are very much left to get on with the job - there is a handsoff management style that not even the arrival of Roche, with its 60 per cent stake in the company, seems to have changed. "There really is an attitude here that if there's something that is really novel and exciting from a purely scientific point of view, then it's worth pursuing", says biochemical all-rounder Joffre Baker, director of Cardiovascular Research, who came west after eight years in Kansas; "and there is a faith that - even though it's not exactly clear what's going to come out of it - then it may well turn into something that's of practical value as well. That's something that the founders believed early on, the idea that you do good science and everything'll come out $\mathrm{OK}$ in the end."

Because the company devotes half its $\$ 500$ million annual income (all of it from product sales) to research and development, these projects can get off the ground at tremendous speed with the minimum of bureaucracy. Larry Lasky came here from Caltech 11 years ago. Sometime later, at Genentech, he was working on a project to develop soluble CD4 as a candidate AIDS vaccine. It did not work, so he decided instead to try out the burgeoning field of selectins, with half an eye

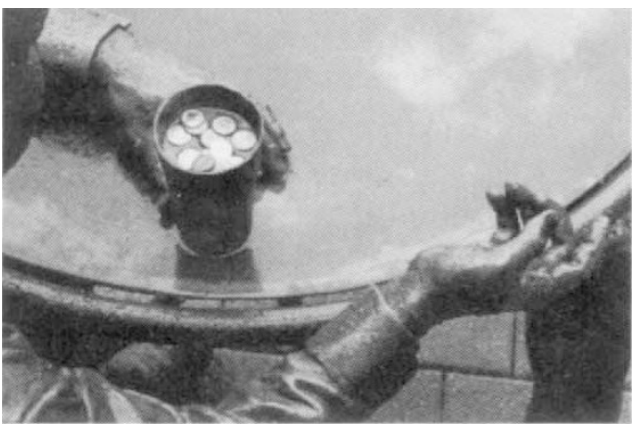
oney in the beer mugs.

on their possible role in inflammation. The project was off the ground within weeks. "If you get an idea at Genentech, within a couple of weeks you can put it into practice. The speed that you can do things is incredible", he says. And because of the on-site process engineering, the facility to make industrial quantities of protein is just across the street.

The mid-to-late $1980 \mathrm{~s}$ were a time of rapid expansion for the company, and the problem became one of managing a workforce of over 2,000 without losing sight of scientific objectives. Genentech is now in the strange position of being a mature company in an industry that is still developing at breakneck speed. Given that California's lack of tradition or established values has been a factor in the propensity of its people to try new ideas, it will be interesting to see whether its deliberate acquisition of hagiographic baggage will slow it down. "There's no doubt that the meeting between Bob and Herb is legendary now", says Lasky. The money in the mugs, though, is a kind of self-deprecation, combined with youthful high spirits (most people here are thirtysomething.) "Genentech has always been a place where humour is very important", Lasky says, "practical jokes, piefights, and immature activities have always been a part of this place. I hope they always will be. It's playfulness." Phil Berman is one of the older members of staff, but declines to reveal just how old. "I'm very immature for my age", he admits.

\section{BIOTECHNOLOGY \\ Adventure capital}

BEHIND every Herb Boyer or Bill Rutter, of course, there is a venture capitalist like Brook Byers of Kleiner Perkins Caufield and Byers, a firm highly rated for its skill in nurturing start-up companies.. Venture capitalists are entrepreneurs who do technology transfer: from a scientist with a big idea, they assemble the management team, hire the scientists, put together physical plant, and most of all, get hold of the money. Clearly not everyone is cut out for this kind of work - not

Brook Byers: has nurtured 31 biotechnology ventures.

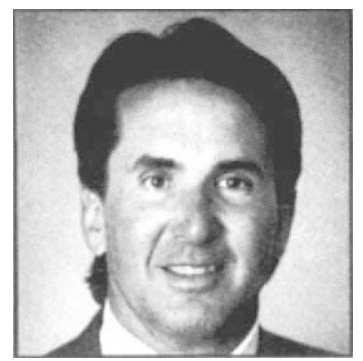

only do venture capitalists have to be more scientifically literate than most scientists, they have to talk the same language as the financiers - especially if they are asking for large sums to underwrite ventures that are speculative, by definition. "It's a very unusual profession", says Byers.

And as with many unusual professions, California provides a more sympathetic environment than perhaps anywhere else. "There are about 300 venture capital firms in the US", says Byers, "and half of them are in California."

Apart from the high concentration of fine science, venture capitalism took root on the West Coast because of attitude. "It's a different kind of investing", Byers explains. "It's an investing style that's very active, it's very committed, that requires a lot of passion and involvement. It's not passive. It's not negotiating the terms of the deal - that's really not done. The real risk in these companies is 'can you get the science to work?', it's not 'did you get 50 cents a share less price?' In the end all that matters is was it a really big idea, a major breakthrough." 